Article

\title{
Leaching Behavior and Potential Environmental Effects of Trace Elements in Coal Gangue of an Open-Cast Coal Mine Area, Inner Mongolia, China
}

\author{
Liu Yang ${ }^{1, *}$, Jianfei Song ${ }^{1}$, Xue Bai ${ }^{2}$, Bo Song ${ }^{1}$, Ruduo Wang ${ }^{1}$, Tianhao Zhou ${ }^{1}$, Jianli Jia ${ }^{1}$ \\ and Haixia $\mathrm{Pu}^{3}$ \\ 1 College of Geoscience and Surveying Engineering, China University of Mining and Technology, \\ Beijing 100083, China; songjianfeiii@gmail.com (J.S.); songbo529@gmail.com (B.S.); \\ ruduowang@gmail.com (R.W.); tian675677299@gmail.com (T.Z.); jjl@cumtb.edu.cn (J.J.) \\ 2 Branch of Resources and Environment, China National Institute of Standardization, \\ Beijing 100088, China; baixue@cnis.gov.cn \\ 3 Institute of Geographic Sciences and Natural Resources Research, Chinese Academy of Sciences, \\ Beijing 100101, China; puhx.14b@igsnrr.ac.cn \\ * Correspondence: 108889@cumtb.edu.cn; Tel.: +86-10-6233-1180
}

Academic Editors: Shifeng Dai, William Skinner and Anna H. Kaksonen

Received: 28 February 2016; Accepted: 6 May 2016; Published: 27 May 2016

\begin{abstract}
In order to better understand the role of coal gangue in potential environmental and ecological risks, the leaching behavior of trace elements from coal gangue has been investigated in an open-cast coal mine, Inner Mongolia, China. Four comparative column leaching experiments were conducted to investigate the impacts of leaching time, $\mathrm{pH}$ values and sample amount on the leaching behavior of trace elements. Enrichment factors (EF), maximum leached amount $\left(L_{a m}\right)$, maximum leachability $\left(L_{r m}\right)$, effects range low (ERL) and effects range median (ERM) were employed to evaluate potential environmental and ecological hazards resulting from the leaching behavior of environment-sensitive trace elements from coal gangue. Leaching time and sample amount display important effects on trace element concentrations, leached amounts and leachability. The $\mathrm{pH}$ values exhibit a weak influence on the leaching behavior of the selected trace elements (e.g., As, $\mathrm{V}, \mathrm{Cr}, \mathrm{Co}, \mathrm{Ni}$, $\mathrm{Cu}, \mathrm{Zn}, \mathrm{Se}, \mathrm{Cd}, \mathrm{Sn}, \mathrm{Pb}$ and $\mathrm{Hg}$ ). The coal gangue are enriched in $\mathrm{As}, \mathrm{Co}$, Se and $\mathrm{Pb}$ and, in particular, show higher environmental pollution levels of $A s$ and $\mathrm{Se}(\mathrm{EF}>2)$. Lam values suggest that all of the elements investigated do not show potential risk to soils and vegetation, but have a high hazard risk for ground water. Elements including $\mathrm{Ni}, \mathrm{As}, \mathrm{Cr}$ and $\mathrm{Zn}$ are inclined to show high or moderate biological toxicity.
\end{abstract}

Keywords: coal gangue; environment-sensitive trace elements; column leaching; leaching behavior; environmental hazard; ecological risk

\section{Introduction}

In recent years, coal has accounted for $74 \%$ of China's total primary energy consumption and will continue to be the major energy source in the next decades [1]. However, environmental hazards were caused as a result of the release and dispersal of harmful trace elements contained in coal, coal gangue and coal combustion residues [2-5]. The rapid development of coal mining in China over the last twenty years has led to a huge coal gangue accumulation in coalfields. According to the incomplete statistics of 2010, there were more than 4.5 billion tons of coal gangue, which covered approximately 1.5 thousands square kilometers of land in China [6]. This could result in substantial environmental hazard and ecological risk, such as soil and water pollution and ecological deterioration, if reasonable precautions are not taken $[7,8]$. 
Coal gangue, a mixture of rocks derived from coal bed's roof, floor, partings and coal itself, is mainly produced from coal mining and, in some cases, is enriched in some toxic trace elements [9-11]. Trace elements are defined as elements with concentrations lower than $0.1 \%$ in coal gangue [12]; they have become a hot topic due to the complex changes of their particles, inability to decompose in natural processes and high toxicity to ecosystems following their release and dispersal into the atmosphere, soils, water and vegetation through the pathways of leaching, weathering and spontaneous combustion $[6,9,13,14]$. Leaching has proven to be one of the primary pathways for trace elements entering into the ecosystem. Extensive studies on the leaching behavior of trace elements from coal, coal fly ash and bottom ash have been conducted [13,15-17]. However, studies focused on the leaching behavior of trace elements from coal gangue are relatively rare [6,18], especially from coal gangue piles. Nevertheless, "leaching behavior" and its impact factors are not clearly defined in these current investigations.

Time is one of the important impact factors on the leaching behavior of trace elements from coal gangue $[4,19,20]$. The integrative efforts to determine the leaching behavior of the selected trace elements from coal gangue piles indicated that it is a very complex process in terms of the leaching pathways, which might be influenced by various factors. Moreover, the potential environmental impacts of the resulting leachates from coal gangue should be given more attention and studied extensively using quantitative assessment methods due to their emergent potential pollution and toxicity.

Therefore, this study was conducted to focus on investigations on the leaching behavior of trace elements from coal gangue piles and their environmental effects. Based on the comparative column leaching experiments, the environmental and ecological risks generated by the trace elements of the resulting leachates from coal gangue piles were evaluated in detail by different semi-quantitative methods. The leaching behavior of the trace elements from coal gangue piles, in this study, mainly refers to the leached concentrations of trace elements, leached amount, leachability, maximum leached amount $\left(L_{a m}\right)$ and maximum leachability $\left(L_{r m}\right)$. The roles of the impact factors, including leaching time, $\mathrm{pH}$ of the leaching solution and sample amount, were simultaneously analyzed.

Twenty-six trace elements in coal, proposed by Swaine [12], could lead to potential environmental impacts, including $\mathrm{As}, \mathrm{Cr}, \mathrm{Cd}, \mathrm{Hg}, \mathrm{Pb}, \mathrm{Se}, \mathrm{B}, \mathrm{Mn}, \mathrm{Ni}, \mathrm{Cu}, \mathrm{V}, \mathrm{Zn}, \mathrm{Co}, \mathrm{Sn}, \mathrm{Cl}, \mathrm{F}, \mathrm{Mo}, \mathrm{Bo}, \mathrm{P}, \mathrm{Th}, \mathrm{U}$, $\mathrm{Ba}, \mathrm{I}, \mathrm{Ra}, \mathrm{Sb}$ and Tl. Particularly, elements $\mathrm{As}, \mathrm{Cd}, \mathrm{Cr}, \mathrm{Hg}, \mathrm{Pb}$ and Se are of most environmental importance [12], while elements $\mathrm{Ni}, \mathrm{Cu}, \mathrm{V}, \mathrm{Zn}, \mathrm{Co}$ and $\mathrm{Sn}$ have generally been analyzed in other leaching experiments [6,8]. Twelve trace elements, including As, $\mathrm{V}, \mathrm{Cr}, \mathrm{Co}, \mathrm{Ni}, \mathrm{Cu}, \mathrm{Zn}, \mathrm{Se}, \mathrm{Cd}, \mathrm{Sn}, \mathrm{Pb}$ and $\mathrm{Hg}$, were therefore selected for investigation in this study, to assess their leaching behavior in coal gangue piles and the corresponding environmental and ecological hazards levels.

\section{Materials and Methods}

\subsection{Study Area}

The Wulantuga open-cast germanium coal mine area $\left(43^{\circ} 56^{\prime} 57.86^{\prime \prime} \mathrm{N}, 115^{\circ} 54^{\prime} 37.36^{\prime \prime} \mathrm{E}\right)$, covering an area of $2.2 \mathrm{~km}^{2}$ [21,22], is located in the southwest of the Shengli Coalfield (with a total area of $342 \mathrm{~km}^{2}$ [21]) in northeastern Inner Mongolia, northern China (Figure 1). The germanium-rich coal in the open-cast mine has been mined since 1997. The production of raw coal was 7.3 million tons in 2014, resulting in approximately 0.7 million tons of coal gangue accumulation [23]. The coal properties and the geological setting have previously been described in a great detail [21,22,24-26].

The study area has a semi-arid continental climate of the middle temperate zone. The annual average temperature is $0-3{ }^{\circ} \mathrm{C}$, and the mean annual rainfall is approximately $276.3 \mathrm{~mm}$. The soil type is chestnut soil, and the vegetation type is typical grassland, with $50 \%$ coverage. There is a seasonal river named the Xilin River flowing northward, $12 \mathrm{~km}$ from the east of the open-cast coal mine area, which has no direct hydraulic connection to the coal mine. The terrain of the Shengli Coalfield is gentle, with a slope of no more than $7^{\circ}$ and an elevation of 1061-1196 $\mathrm{m}$. The germanium coal mine 
area belongs to an approximate level-slight inclination monocline structure, with a formation dip of less than $5^{\circ}$.

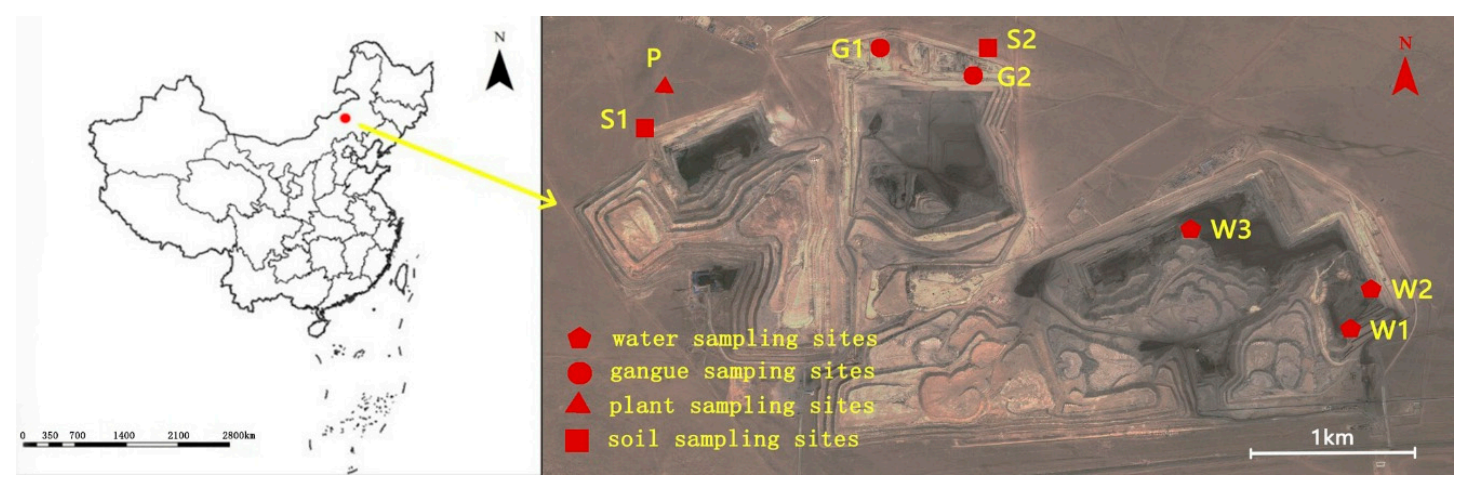

Figure 1. Study area and sample location in the open-cast germanium coal-mine area, Inner Mongolia, China.

\subsection{Sample Collection}

To investigate the mineral and chemical compositions in coal gangue and their potential environmental effects, coal gangue samples were collected in the open-cast germanium coal mine in July 2014, as well as the soils, water and plant samples around the mine area (Figure 1).

Coal gangue samples were selected from two sites of coal gangue piles in study area (Figure 1). Three samples were taken by hand and were immediately stored in individual sealed plastic bags in order to avoid any contamination and oxidation. Soil samples were collected from two sites in the north of the open-cast coal mine area using a geotome at a depth of $0-15 \mathrm{~cm}$ of each layer (Figure 2), and three sampling points were set in each layer, according to the sample collection methods described in detail by Jia et al. [23]. Background soil samples were taken from the grassland located approximately $15 \mathrm{~km}$ to the northeast of Xilinhaote city. All of the soil samples were also stored in sealed plastic bags in a portable freezer to minimize possible changes and contaminations. Three water samples were taken using a glass water sampler with $2 \mathrm{~L}$ capacity from the water pools in the open-cast germanium coal mine area. Two background samples were collected from the Jiuquwan Reservoir, which is situated approximately $20 \mathrm{~km}$ from the southeast of the coal mine area. The samples were immediately put into polyethylene terephthalate (PET) bottles and stored in the portable freezer. Four plant samples (Filifolium Kitam, Artemisia lavandulaefolia, Allium tuberosum Rottler and Leymus chinensis (Trin.) Tzvel) were selected in the grassland located in the north of the coal mine area. The leaves and trunks of plant samples were collected and immediately stored in sealed plastic bags.

\subsection{Analytical Methods}

The contents of major-element oxides, including $\mathrm{SiO}_{2}, \mathrm{TiO}_{2}, \mathrm{Al}_{2} \mathrm{O}_{3}, \mathrm{Fe}_{2} \mathrm{O}_{3}, \mathrm{MgO}, \mathrm{CaO}, \mathrm{MnO}$, $\mathrm{Na}_{2} \mathrm{O}, \mathrm{K}_{2} \mathrm{O}$ and $\mathrm{P}_{2} \mathrm{O}_{5}$, in coal gangue samples were analyzed by $\mathrm{X}$-ray fluorescence spectrometry (XRF, ARL ADVANT ${ }^{\prime} \mathrm{XP}+$, ThermoFisher, Waltham, MA, USA) as outlined by Dai et al. [27]. The mineralogical compositions were determined on a D/max-2500/PC powder diffractometer with $\mathrm{Ni}$-filtered $\mathrm{Cu}-\mathrm{K} \alpha$ radiation and a scintillation detector. Each XRD pattern was recorded over a $2 \theta$ interval of $2.6^{\circ}-70^{\circ}$, with a step size of $0.01^{\circ}$ [27]. The selected environmentally-sensitive trace elements were $\mathrm{As}, \mathrm{V}, \mathrm{Cr}, \mathrm{Co}, \mathrm{Ni}, \mathrm{Cu}, \mathrm{Zn}, \mathrm{Se}, \mathrm{Cd}, \mathrm{Sn}, \mathrm{Pb}$ and $\mathrm{Hg}$. The trace element contents of $\mathrm{V}, \mathrm{Cr}, \mathrm{Co}, \mathrm{Ni}$, $\mathrm{Cu}, \mathrm{Zn}, \mathrm{Cd}, \mathrm{Sn}$ and $\mathrm{Pb}$ in the coal gangue, soil, water and plant samples and those in the resulting leachates of the following experiments of coal gangue were all determined by inductively-coupled plasma mass spectrometry (X series II ICP-MS, ThermoFisher), according to the procedures described in detail by Dai et al. [28]. Arsenic and Se were determined by ICP-MS using collision cell technology (CCT), as described by Li et al. [29]. The concentration of $\mathrm{Hg}$ was determined by a Milestone DMA-80 $\mathrm{Hg}$ analyzer (Milestone, Sorisole, Italy). The detection limit of $\mathrm{Hg}$ is $0.005 \mathrm{ng}$; the relative standard 
deviation from eleven runs on $\mathrm{Hg}$ standard reference is $1.5 \%$; and the linearity of the calibration is in the range 0-1000 ng [30]. The handling methods of soil samples were described in detail by Jia et al. [24]. Four plant samples were mixed and were cleaned by deionized water. They were dried in a drying oven $\left(60^{\circ} \mathrm{C}\right)$ and crushed to 100 mesh size for testing.
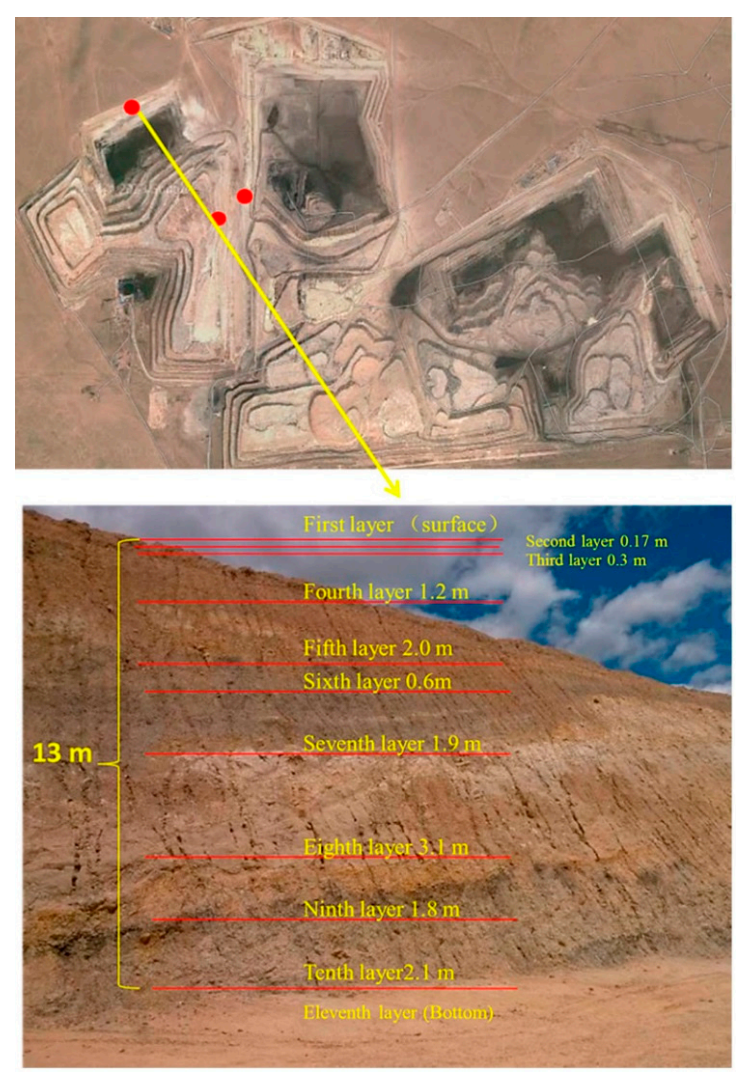

Figure 2. The distribution of soil sampling points and sections in the mining area [23].

\subsection{Leaching Experiments}

Coal gangue samples were air-dried and crushed to 200 mesh. They were blended by the method of repeated division into four equal portions to mix thoroughly (four times) and prepared for the leaching experiments $(5 \mathrm{~kg})$. Then, three 30 -g sub-samples and one $45-\mathrm{g}$ sub-sample were obtained by an analytical balance of $0.01-\mathrm{mg}$ precision, accurate to four decimal places.

To investigate the impacts of different $\mathrm{pH}$ values and sample quantities on the leaching behavior of the selected trace elements in the coal gangue, four column leaching experimental groups were determined in this study (Table 1). The $\mathrm{pH}$ of the rainfall in the study area is approximately $6.60-8.19$, slightly alkaline, with no acid rain. The concentration ratio between $\mathrm{SO}_{4}{ }^{2-}$ and $\mathrm{NO}_{3}{ }^{-}$ in the rainfall is approximately 2.3-29.0, suggesting sulfate precipitation [19,31]. According to the rainfall characteristics, distilled water $(\mathrm{pH}=7.0 \pm 0.3)$, acidic solution $(\mathrm{pH}=6.0 \pm 0.3$, using distilled water with $\mathrm{H}_{2} \mathrm{SO}_{4}$ ) and alkaline solution $(\mathrm{pH}=8.0 \pm 0.3$, using distilled water with $\mathrm{NaOH}$ ) were prepared for the leaching experimental groups. In this study, Experiments I, II and III were set for detecting the effects of solution $\mathrm{pH}$ on leaching behavior, with the same sample weight of $30-\mathrm{g}$, and different solutions of acid, alkaline and neutral $\mathrm{pH}$, respectively. All of the test utensils were soaked in a $14 \% \mathrm{HNO}_{3}$ solution for $24 \mathrm{~h}$ and rinsed by distilled water before the leaching experiments [19].

Each coal gangue sample was transferred into a fixed glass column, which was $30 \mathrm{~mm}$ in internal diameter and $50 \mathrm{~cm}$ in length (Figure 3). Quartz sand (10 g, particle size $<0.83 \mathrm{~mm}$ ) was packed into the bottom of the column in Experiments I, III and IV, respectively, to prevent fine particle loss during leaching. It was also packed at the top of the sample to make the solution disperse uniformly. However, 
a small amount of absorbent cotton, instead of quartz sand, was used at the top and bottom of the column in Experiment II. This was to prevent the quartz sand from reacting with the alkaline solution, in which absorbent cotton could not be dissolved. The four solutions were controlled in terms of influx into the columns at room temperature. The experiments lasted for $90 \mathrm{~h}$. The resulting leachates were sampled once every $3 \mathrm{~h}$ and then put into 50-mL volumetric tubes for element analysis. Thirty samples were obtained from each experimental group. As a matter of convenience for displaying and analyzing the results, the concentrations of the 30 samples were averaged over 10 time units, i.e., $0-9 \mathrm{~h}, 9-18 \mathrm{~h}$, 18-27 h, 27-36 h, 36-45 h, 45-54 h, 54-63 h, 63-72 h, 72-81 h and 81-90 h.

Table 1. Test setting data for the four column leaching experimental groups.

\begin{tabular}{cccc}
\hline Group & Weight of Samples (g) & pH of Solution & Test Purpose \\
\hline I & 30 & $6.0 \pm 0.3$ & acid solution \\
II & 30 & $8.0 \pm 0.3$ & alkaline solution \\
III & 30 & $7.0 \pm 0.3$ & neutral solution \\
IV & 45 & $7.0 \pm 0.3$ & different weight of samples \\
\hline
\end{tabular}

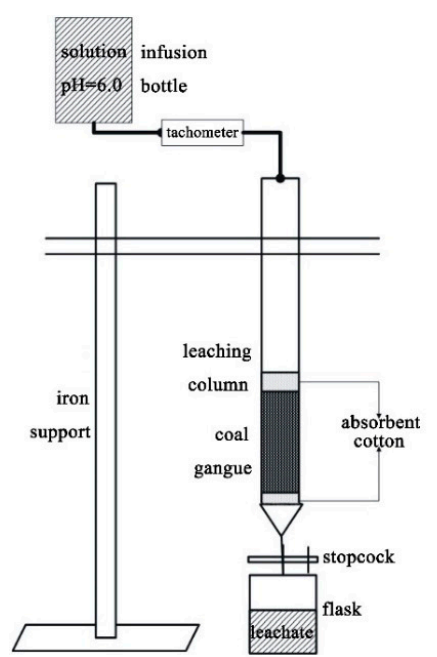

( I )

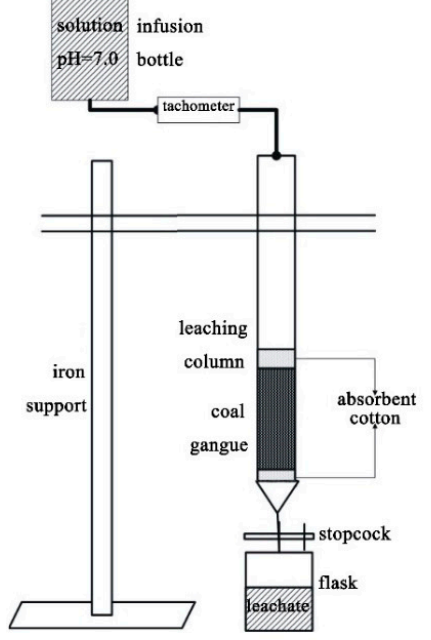

(III)

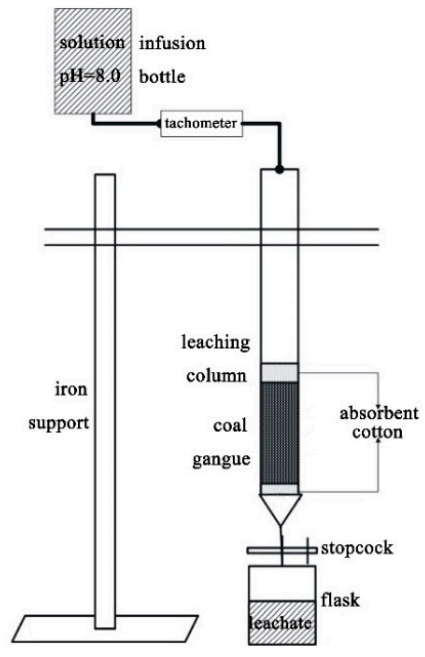

(II)

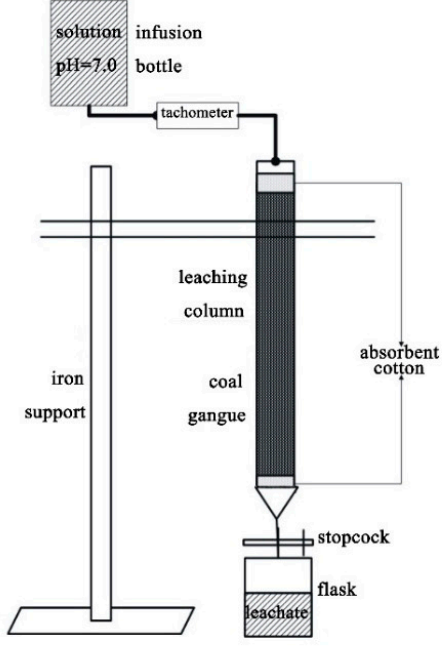

(IV)

Figure 3. Installations of the leaching experiments: I, II, III and IV. Experiment I, 30-g samples, $\mathrm{pH}=6.0 \pm 0.3$; Experiment II, 30-g samples, $\mathrm{pH}=8.0 \pm 0.3$; Experiment III, 30-g samples, $\mathrm{pH}=7.0 \pm 0.3$; Experiment III, 45-g samples, $\mathrm{pH}=7.0 \pm 0.3$. 
The "leachability $\left(L_{r}\right)$ ", "leached concentration $\left(C_{l}\right)$ " and "maximum leached concentration $\left(C_{l m}\right)$ " were used to analyze the leaching behavior of the coal gangue during the four experimental groups. $L_{r}$ $(\%)$ is calculated by Equation (1), and $C_{l m}(\mu \mathrm{g} / \mathrm{L})$ was calculated by Equation (2):

$$
\begin{aligned}
& L_{r}=\frac{100 C_{l x} \times V_{x}}{M_{x}} \\
& C_{l m}=\operatorname{Max}\left(C_{l x}\right)
\end{aligned}
$$

where $C_{l x}(\mu \mathrm{g} / \mathrm{L})$ and $V_{x}(\mathrm{~L})$ represent the concentration of an element and the volume of the resulting leachates, respectively, during a period of leaching time. $M_{x}(\mu \mathrm{g})$ is the total mass of an element in the coal gangue samples.

\subsection{Environmental Effect Indicators}

To compare the concentrations of an element in coal gangue with black shales, Clarke values were used as a practical method of assessing trace element enrichment [6]. The enrichment factor (EF) was then an important parameter to evaluate the pollution level of an element [6,32-34]. EF values of elements in coal gangue, coal, soil, water and vegetation of the Wulantuga open-cast coal mine were applied to assess the pollution degrees of the 12 trace elements. The EF value is expressed as follows:

$$
E F=\frac{A_{i} / C}{B_{i} / D}
$$

where $A_{i}(\mu \mathrm{g} / \mathrm{g})$ is an element's concentration; $B_{i}(\mu \mathrm{g} / \mathrm{g})$ is the background value of an element (Clarke value); $C(\mu \mathrm{g} / \mathrm{g})$ is the reference element concentration; $D(\mu \mathrm{g} / \mathrm{g})$ is the Clarke value of the reference element. Scandium is usually used as the reference element due to its stable concentration, and it was also applied in this study.

"Maximum leached amount" $\left(L_{a m}\right)$ and "maximum leachability" $\left(L_{r m}\right)$ are important indicators for trace element environmental risk assessment, which could provide valuable information of the maximum extent of element migrating ability [4,33]. The value of $L_{a m}$ is defined here as the ratio of all amounts of an element in the leachates of $90 \mathrm{~h}$ to the mass of the coal gangue sample. The value of $L_{r m}$ is based on the ratio of the amount of the trace element in the leachates after $90 \mathrm{~h}$ to the mass of the trace element in the coal gangue sample.

Aimed at further evaluating the environmental threat of the 12 environmentally-sensitive elements, the concentration limits of the trace elements in groundwater, soil and food were also compared in this research. Furthermore, the effects range low (ERL) and effects range median (ERM), defined in international sediment quality guidelines (SQGs), were adopted in this study to assess the ecological risk, namely the biological toxicity of trace elements in coal gangue. ERL values are the concentrations below which adverse effects on sediment-dwelling fauna would be unlikely, and ERM values were, in contrast, the concentrations above which adverse effects are likely [5,34]. The existence of biological toxicity could be divided into three levels, i.e., $<$ ERL, very low toxicity, $>$ ERL and $<$ ERM, middle toxicity, and >ERM, probable toxicity [35].

The environmental quality standard for soils, the quality standard for groundwater and limits of contaminants in foods were also applied to be compared with the $L_{a m}$ values of the trace elements in soil samples, water samples and vegetation samples, respectively, in the study. Unfortunately, there are no specific limits, standards or references of the trace element concentrations for plants. Therefore, the concentrations in vegetation samples had to be compared to the limits of contaminants in foods, the alternative comparing reference, for evaluating the environmental impacts of coal gangue leaching on vegetation. 


\section{Results}

\subsection{Chemistry and Mineralogy in Coal Gangue}

Proximate and sulfur analyses were performed on the coal gangue sample. Proximate analysis on coal or/and coal gangue samples is long-term, well-established term in coal industry and covers the determination of moisture, volatile matter and ash yield in samples [36]. These data are expressed as percentages of the air-dried coal gangue (on an air dry basis; Table 2), and these include the air-dried moisture, but do not involve the surface moisture of the samples [36-39].

Table 2. Contents (wt \%) of coal gangue samples in the Wulantuga open-cast coal mine area.

\begin{tabular}{|c|c|c|c|c|c|c|c|c|c|c|c|c|}
\hline \multicolumn{3}{|c|}{ Proximate and Sulfur Analysis } & \multicolumn{10}{|c|}{ Chemical Compositions } \\
\hline $\mathrm{A}_{\mathrm{ad}}$ & $\mathrm{M}_{\mathrm{ad}}$ & $\mathrm{S}_{\mathrm{td}}$ & $\mathrm{SiO}_{2}$ & $\mathrm{Al}_{2} \mathrm{O}_{3}$ & $\mathrm{Fe}_{2} \mathrm{O}_{3}$ & $\mathrm{~K}_{2} \mathrm{O}$ & $\mathrm{MgO}$ & $\mathrm{TiO}_{2}$ & $\mathrm{CaO}$ & $\mathrm{Na}_{2} \mathrm{O}$ & $\mathrm{P}_{2} \mathrm{O}_{5}$ & $\mathrm{MnO}$ \\
\hline 90.30 & 9.70 & 0.07 & 70.26 & 19.23 & 3.76 & 3.15 & 1.31 & 1.10 & 0.50 & 0.40 & 0.04 & 0.04 \\
\hline
\end{tabular}

The coal gangue samples are dominated by $\mathrm{SiO}_{2}(70.26 \%)$ and $\mathrm{Al}_{2} \mathrm{O}_{3}(19.23 \%)$, followed by $\mathrm{Fe}_{2} \mathrm{O}_{3}$ $(3.76 \%)$ and $\mathrm{K}_{2} \mathrm{O}(3.15 \%)$ (Table 2$)$, along with trace percentages of $\mathrm{MgO}(1.31 \%), \mathrm{TiO}_{2}(1.10 \%), \mathrm{CaO}$ $(0.50 \%)$ and $\mathrm{Na}_{2} \mathrm{O}(0.40 \%)$.

The XRD patterns showed that the main mineral phases found in the coal gangue samples were montmorillonite, illite mixed layer, kaolinite and quartz. The dominant minerals of montmorillonite and kaolinite indicated that the coal gangue in the Wulantuga open-cast coal mine area had a high expansibility.

In comparison to the world Clarke values, the concentration of the coal gangue was enriched in Co (the average concentration equaled $53.92 \mu \mathrm{g} / \mathrm{g}$ in study area) and depleted in Se, Cd and $\mathrm{Hg}$. The remains of the selected 12 trace elements were close to the concentrations of the world Clarke values (Table 3 ).

\subsection{Leaching Characteristics of Coal Gangue}

\subsubsection{Leaching Time}

Eight different trend curves for the leached concentration of 12 elements, which were changed by leaching time, could be identified in the four leaching tests (Tables 4-7). Among them, a sharp drop followed by a steady curve was the major trend, which accounted for more than one third of the concentration time changing curves. This trend curve was observed for elements $\mathrm{Co}, \mathrm{Ni}, \mathrm{Se}, \mathrm{Cu}, \mathrm{Zn}$ and $\mathrm{Pb}$. Descending curves and curves with a short rise followed by a large decline accounted for $20.83 \%$ and $14.58 \%$ of the trends, respectively. Elements $\mathrm{Cr}$, As and $\mathrm{Cu}$ exhibited descending curves. Short rise, large decline curves were observed for $\mathrm{V}$ and As. These three trends, in general, showed higher extractable concentrations of the elements in the initial leaching phase, but decreased sharply or gradually as the leaching time goes on. Steady descending curves (14.58\% of all of the trends), i.e., concentrations of the elements decreased slightly during the whole leaching time, were observed for the elements Cd, Sn and Hg. A wave-like curve in decreasing order of significance accounted for $4.17 \%$, including Zn. Double wave-like curves contributed to $2.08 \%$, showing a slight and steady decrease order for elements of $\mathrm{Cd}$ and $\mathrm{Hg}$. A curve with a slight and steady rise followed by a decline $(2.08 \%$ of all of the trends) was observed for $\mathrm{Sn}$. Based on these trends, the elements could be divided into two categories. Elements $\mathrm{Co}, \mathrm{Ni}, \mathrm{Se}, \mathrm{Cu}, \mathrm{Zn}, \mathrm{Pb}, \mathrm{Cr}$, As and $\mathrm{V}$ were in the category with a sharp initial decrease in the leaching phase, followed by a steady decline. Elements $\mathrm{Cd}, \mathrm{Hg}$ and $\mathrm{Sn}$ were in the category with characteristics of slight and steady waves, decreasing throughout the leaching phases. 
Table 3. Concentrations of the 12 elements in coal gangue, soil, water and vegetation in the Wulantuga open-cast coal mine area. SQGs, sediment quality guidelines.

\begin{tabular}{|c|c|c|c|c|c|c|c|c|c|c|c|c|c|c|c|}
\hline \multirow{2}{*}{ Elements } & \multicolumn{4}{|c|}{ Coal Gangue $(\mu \mathrm{g} / \mathrm{g})$} & \multicolumn{2}{|c|}{ Soil $(\mu \mathrm{g} / \mathrm{g})$} & \multicolumn{2}{|c|}{ Water $(\mu \mathrm{g} / \mathrm{L})$} & \multicolumn{2}{|c|}{ Vegetation $(\mu \mathrm{g} / \mathrm{g})$} & \multirow{2}{*}{$\begin{array}{l}\text { Clarke } \\
\text { Value }^{2}\end{array}$} & \multirow{2}{*}{$\begin{array}{c}\text { ERL-ERM } \\
(\mu \mathrm{g} / \mathrm{g})\end{array}$} & \multicolumn{3}{|c|}{$\%$ of Samples amongst Ranges of SQGs } \\
\hline & Min-Max & $\mathrm{AC}$ & World Coal Gangue $^{1}$ & EF & AC & EF & $\mathrm{AC}$ & EF & $\mathrm{AC}$ & EF & & & $<$ ERL & $>$ ERL and $<$ ERM & $>$ ERM \\
\hline As & $7.35-28.53$ & 17.94 & $10-80$ & 4.86 & 30.87 & 9.08 & 8.30 & 41.07 & 3.91 & 3.78 & 1.8 & $8.2-70$ & 50 & 50 & 0 \\
\hline $\mathrm{V}$ & $107.33-107.35$ & 107.34 & $100-400$ & 0.39 & 99.74 & 0.39 & 1.93 & 0.13 & 18.99 & 0.24 & 135 & & & & \\
\hline $\mathrm{Cr}$ & $72.48-94.46$ & 83.47 & $50-160$ & 0.41 & 92.82 & 0.49 & 1.10 & 0.10 & 161.53 & 2.81 & 100 & $81-370$ & 50 & 50 & 0 \\
\hline Co & $29.64-78.21$ & 53.92 & $10-30$ & 1.05 & 12.55 & 0.27 & 0.59 & 0.21 & 2.68 & 0.19 & 25 & & & & \\
\hline $\mathrm{Ni}$ & $28.38-52.88$ & 40.63 & $40-140$ & 0.26 & 23.56 & 0.17 & 1.63 & 0.19 & 15.54 & 0.36 & 75 & $20.9-51.6$ & 0 & 50 & 50 \\
\hline $\mathrm{Cu}$ & $34.58-44.97$ & 39.77 & $35-150$ & 0.35 & 32.44 & 0.31 & 5.01 & 0.81 & 25.65 & 0.81 & 55 & $34-270$ & 0 & 100 & 0 \\
\hline $\mathrm{Zn}$ & $127.41-155.31$ & 141.36 & $60-300$ & 0.99 & 104.48 & 0.79 & 17.55 & 2.23 & 30.54 & 0.76 & 70 & $150-410$ & 50 & 50 & 0 \\
\hline $\mathrm{Se}$ & $0.36-1.16$ & 0.76 & $3-30$ & 7.41 & 0.53 & 5.61 & 3.51 & 625.26 & 0.45 & 15.67 & 0.05 & & & & \\
\hline $\mathrm{Cd}$ & $0.36-0.41$ & 0.39 & $2-12$ & 0.95 & 0.44 & 1.17 & 0.01 & 0.45 & 0.14 & 1.22 & 0.2 & & & & \\
\hline Sn & $3.98-4.01$ & 4.00 & $2-10$ & 0.98 & 4.46 & 1.18 & -0.02 & 0.09 & 0.35 & 0.30 & 2 & & & & \\
\hline $\mathrm{Pb}$ & $26.40-28.39$ & 27.39 & $10-40$ & 1.07 & 24.00 & 1.02 & -0.08 & 0.06 & 5.99 & 0.83 & 12.5 & & & & \\
\hline $\mathrm{Hg}$ & $0.09-0.17$ & 0.13 & $0.2-0.6$ & 0.79 & 0.08 & 0.53 & $\mathrm{Nd}$ & 0.00 & 0.03 & 0.65 & 0.08 & & & & \\
\hline Sc & $44.72-45.48$ & 45.10 & & & 41.54 & & 2.47 & & 12.63 & & & & & & \\
\hline
\end{tabular}

${ }^{1}$ From Zhou et al. [6]; ${ }^{2}$ from Taylor. [40]; AC, average concentration; EF, enrichment factor; ERL, effect range low value; ERM, effect range median value.

Table 4. Analytical concentrations of the selected trace elements in resulting leachates from 0-90 h in Experiment I ( $\mu \mathrm{g} / \mathrm{L})$.

\begin{tabular}{|c|c|c|c|c|c|c|c|c|c|c|c|}
\hline Element & $0-9 \mathrm{~h}$ & 9-18 h & $18-27 \mathrm{~h}$ & $27-36 \mathrm{~h}$ & $36-45 \mathrm{~h}$ & $45-54 \mathrm{~h}$ & $54-63 \mathrm{~h}$ & $63-72 \mathrm{~h}$ & $72-81 \mathrm{~h}$ & $81-90 \mathrm{~h}$ & Trend Curve \\
\hline As & 10.81 & 15.04 & 9.75 & 7.81 & 4.06 & 2.98 & 2.29 & 1.93 & 1.33 & 0.65 & $\curvearrowright$ \\
\hline $\mathrm{V}$ & 33.18 & 35.79 & 24.74 & 19.16 & 14.44 & 12.28 & 9.20 & 8.24 & 5.97 & 3.97 & $\curvearrowright$ \\
\hline $\mathrm{Cr}$ & 8.93 & 6.52 & 4.17 & 3.94 & 3.83 & 3.22 & 2.42 & 2.38 & 2.27 & 2.23 & $\backslash$ \\
\hline Co & 11.08 & 3.24 & 1.46 & 1.27 & 1.26 & 0.92 & 0.50 & 0.34 & 0.48 & 0.51 & $l$ \\
\hline $\mathrm{Ni}$ & 21.64 & 8.40 & 4.09 & 2.48 & 2.16 & 1.36 & 1.34 & 0.58 & 0.63 & 0.58 & l \\
\hline $\mathrm{Cu}$ & 15.60 & 6.72 & 2.52 & 1.35 & 1.10 & 0.57 & 0.21 & 0.05 & 0.00 & 0.00 & l \\
\hline $\mathrm{Zn}$ & 55.93 & 44.25 & 40.47 & 27.60 & 25.87 & 18.37 & 19.73 & 18.09 & 19.19 & 21.83 & l \\
\hline Se & 28.85 & 0.67 & 0.44 & 0.48 & 0.24 & 0.30 & 0.18 & 0.30 & 0.02 & 0.28 & $l$ \\
\hline $\mathrm{Cd}$ & 0.15 & 0.07 & 0.03 & 0.02 & 0.03 & 0.01 & 0.01 & 0.01 & 0.01 & 0.02 & - \\
\hline Sn & 0.37 & 0.22 & 0.11 & 0.09 & 0.09 & 0.07 & 0.02 & 0.01 & 0.01 & 0.01 & $\sim$ \\
\hline $\mathrm{Pb}$ & 3.39 & 1.56 & 0.61 & 0.48 & 0.41 & 0.19 & 0.04 & 0.02 & 0.01 & 0.01 & $\downarrow$ \\
\hline $\mathrm{Hg}$ & 0.19 & 0.16 & 0.11 & 0.09 & 0.07 & 0.23 & 0.12 & 0.08 & 0.09 & 0.09 & - \\
\hline
\end{tabular}


Table 5. Analytical concentrations of the selected trace elements in resulting leachates from $0-90 \mathrm{~h}$ in Experiment II $(\mu \mathrm{g} / \mathrm{L})$.

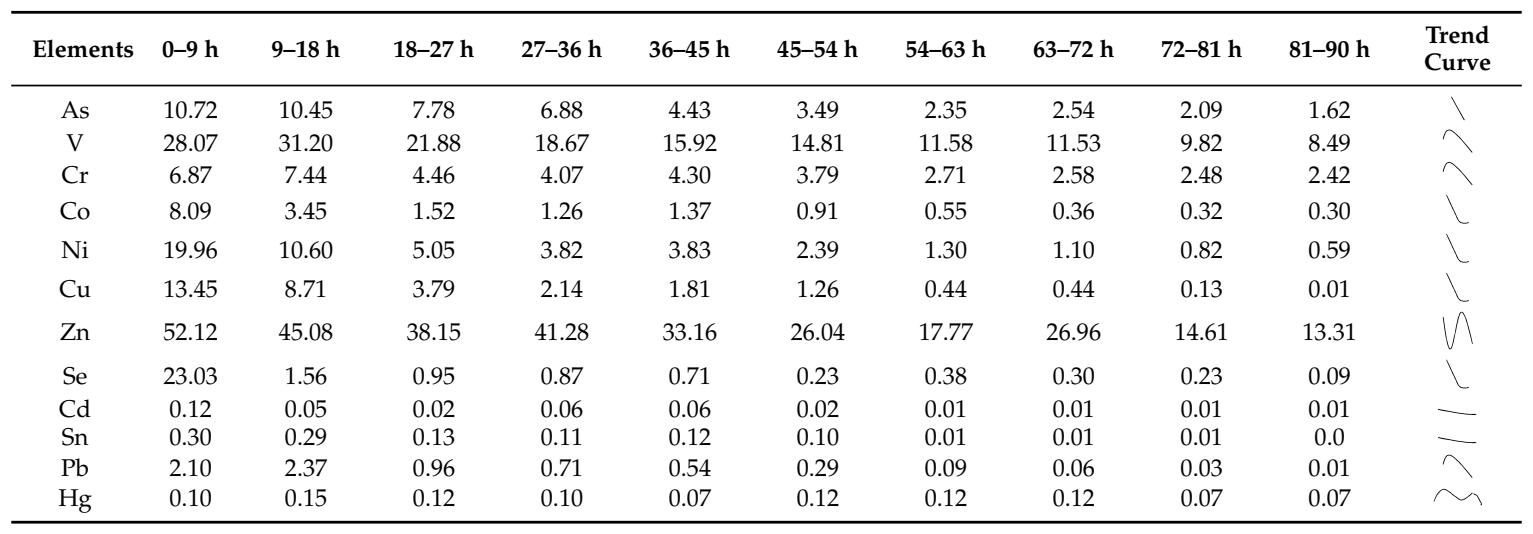

Table 6. Analytical concentrations of the selected trace elements in resulting leachates from $0-90 \mathrm{~h}$ in Experiment III $(\mu \mathrm{g} / \mathrm{L})$.

\begin{tabular}{|c|c|c|c|c|c|c|c|c|c|c|c|}
\hline Elements & $0-9 \mathrm{~h}$ & $9-18 \mathrm{~h}$ & $18-27 \mathrm{~h}$ & $27-36 \mathrm{~h}$ & $36-45 \mathrm{~h}$ & $45-54 \mathrm{~h}$ & $54-63 \mathrm{~h}$ & $63-72 \mathrm{~h}$ & $72-81 \mathrm{~h}$ & $81-90 \mathrm{~h}$ & $\begin{array}{l}\text { Trend } \\
\text { Curve }\end{array}$ \\
\hline As & 13.38 & 16.66 & 15.04 & 12.20 & 4.71 & 3.16 & 1.96 & 1.82 & 1.31 & 0.61 & \\
\hline $\mathrm{Cr}$ & 10.11 & 8.16 & 6.49 & 4.40 & 3.55 & 3.47 & 2.35 & 2.32 & 2.32 & 2.34 & $\backslash$ \\
\hline Co & 10.18 & 3.76 & 1.99 & 1.16 & 1.08 & 0.60 & 0.42 & 0.28 & 0.34 & 0.47 & \\
\hline $\mathrm{Ni}$ & 22.59 & 11.02 & 8.14 & 3.08 & 2.34 & 1.39 & 0.82 & 0.75 & 0.56 & 0.67 & $\checkmark$ \\
\hline $\mathrm{Zn}$ & 68.14 & 49.93 & 59.40 & 43.74 & 38.47 & 18.92 & 21.12 & 25.11 & 14.86 & 19.76 & \\
\hline Se & 25.08 & 1.71 & 0.57 & 0.55 & 0.54 & 0.50 & 0.19 & 0.43 & 0.17 & 0.21 & $\checkmark$ \\
\hline $\mathrm{Cd}$ & 0.12 & 0.05 & 0.27 & 1.36 & 0.04 & 0.02 & 1.72 & 0.08 & 0.05 & 0.02 & $\sim$ \\
\hline Sn & 0.39 & 0.28 & 0.16 & 0.10 & 0.07 & 0.06 & 0.00 & 0.00 & 0.00 & 0.00 & - \\
\hline $\mathrm{Pb}$ & 4.14 & 2.82 & 1.67 & 0.84 & 0.55 & 0.38 & 0.05 & 0.02 & 0.03 & 0.03 & $\backslash$ \\
\hline $\mathrm{Hg}$ & 0.21 & 0.09 & 0.06 & 0.15 & 0.13 & 0.07 & 0.10 & 0.09 & 0.07 & 0.06 & $\sim$ \\
\hline
\end{tabular}

Table 7. Analytical concentrations of the selected trace elements in resulting leachates from $0-90 \mathrm{~h}$ in Experiment IV $(\mu \mathrm{g} / \mathrm{L})$.

\begin{tabular}{|c|c|c|c|c|c|c|c|c|c|c|c|}
\hline Elements & $0-9 \mathrm{~h}$ & 9-18 h & $18-27 \mathrm{~h}$ & $27-36 \mathrm{~h}$ & $36-45 \mathrm{~h}$ & $45-54 \mathrm{~h}$ & $54-63 \mathrm{~h}$ & $63-72 \mathrm{~h}$ & $72-81 \mathrm{~h}$ & $81-90 \mathrm{~h}$ & $\begin{array}{l}\text { Trend } \\
\text { Curve }\end{array}$ \\
\hline As & 12.79 & 11.13 & 11.36 & 11.49 & 8.35 & 7.51 & 6.79 & 6.55 & 6.00 & 4.01 & 1 \\
\hline $\mathrm{V}$ & 59.61 & 43.02 & 42.93 & 36.38 & 35.31 & 31.75 & 23.66 & 21.03 & 18.97 & 14.32 & \\
\hline $\mathrm{Cr}$ & 31.75 & 17.67 & 18.27 & 12.18 & 14.46 & 11.33 & 4.95 & 4.27 & 4.49 & 3.54 & \\
\hline Co & 34.68 & 14.79 & 8.69 & 5.66 & 5.15 & 3.63 & 1.68 & 1.20 & 1.22 & 0.89 & \\
\hline $\mathrm{Ni}$ & 55.24 & 37.17 & 24.41 & 15.49 & 11.69 & 8.17 & 4.30 & 3.01 & 2.65 & 2.65 & \\
\hline Se & 107.20 & 20.83 & 4.56 & 1.90 & 1.46 & 0.94 & 1.11 & 0.71 & 0.68 & 0.50 & \\
\hline $\mathrm{Cd}$ & 0.51 & 0.15 & 0.12 & 0.06 & 0.07 & 0.04 & 0.03 & 0.02 & 0.02 & 0.02 & \\
\hline Sn & 0.29 & 0.65 & 0.67 & 0.49 & 0.60 & 0.47 & 0.10 & 0.06 & 0.07 & 0.10 & \\
\hline $\mathrm{Pb}$ & 17.87 & 8.16 & 7.73 & 4.45 & 4.83 & 3.02 & 0.94 & 0.68 & 0.79 & 0.43 & 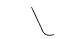 \\
\hline $\mathrm{Hg}$ & 0.25 & 0.10 & 0.10 & 0.09 & 0.05 & 0.15 & 0.08 & 0.05 & 0.06 & 0.05 & 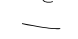 \\
\hline
\end{tabular}

The concentrations of the 12 elements in the resulting leachates reached the maximum at different leaching time periods (Table 8 ). Approximately $70.83 \%$ of the leached concentrations reached the maximum at $0-3 \mathrm{~h}$, especially for elements $\mathrm{Co}, \mathrm{Ni}, \mathrm{Cu}$ and $\mathrm{Se}$. The maximum leach concentration occurred at $12-15 \mathrm{~h}$, accounting for $10.42 \%$. In the other periods of $6-9 \mathrm{~h}, 15-18 \mathrm{~h}, 21-24 \mathrm{~h}, 24-27 \mathrm{~h}$, 27-30 h, 30-33 h, 51-54 h and 60-63 h, the resulting leachates reached the maximum concentration only once $(2.08 \%)$. All 12 selected trace elements could be mostly leached out within no more than $30 \mathrm{~h}$, except for elements $\mathrm{Hg}$ and $\mathrm{Cd}$. 
Table 8. The maximum leached concentrations $\left(C_{l m}\right)$ of the 12 elements from the coal gangue of the Wulantuga open-cast coal mine area $(\mu \mathrm{g} / \mathrm{L})$.

\begin{tabular}{|c|c|c|c|c|c|c|c|c|}
\hline \multirow{2}{*}{ Elements } & \multicolumn{2}{|c|}{ Experiment I } & \multicolumn{2}{|c|}{ Experiment II } & \multicolumn{2}{|c|}{ Experiment III } & \multicolumn{2}{|c|}{ Experiment IV } \\
\hline & $C_{l m}$ & $\mathrm{Tp}(\mathrm{h})$ & $C_{l m}$ & Tp (h) & $C_{l m}$ & $\mathrm{Tp}(\mathrm{h})$ & $C_{l m}$ & $\mathrm{Tp}(\mathrm{h})$ \\
\hline As & 18.19 & $15-18$ & 11.63 & $3-6$ & 17.64 & $27-30$ & 13.99 & $0-3$ \\
\hline $\mathrm{V}$ & 40.07 & $6-9$ & 35.13 & $12-15$ & 45.69 & $12-15$ & 81.15 & $0-3$ \\
\hline $\mathrm{Cr}$ & 11.23 & $0-3$ & 10.21 & $12-15$ & 13.47 & $0-3$ & 49.10 & $0-3$ \\
\hline $\mathrm{Co}$ & 17.76 & $0-3$ & 13.76 & $0-3$ & 16.20 & $0-3$ & 51.15 & $0-3$ \\
\hline $\mathrm{Ni}$ & 27.88 & $0-3$ & 30.57 & $0-3$ & 31.36 & $0-3$ & 67.00 & $0-3$ \\
\hline $\mathrm{Cu}$ & 19.00 & $0-3$ & 14.81 & $0-3$ & 22.76 & $0-3$ & 43.97 & $0-3$ \\
\hline $\mathrm{Zn}$ & 63.55 & $0-3$ & 64.40 & $0-3$ & 93.35 & $24-27$ & 185.60 & $0-3$ \\
\hline Se & 53.50 & $0-3$ & 64.70 & $0-3$ & 49.73 & $0-3$ & 196.90 & $0-3$ \\
\hline $\mathrm{Cd}$ & 0.26 & $0-3$ & 0.24 & $0-3$ & 5.87 & $30-33$ & 0.79 & $0-3$ \\
\hline Sn & 0.48 & $0-3$ & 0.44 & $12-15$ & 0.56 & $0-3$ & 1.07 & $21-24$ \\
\hline $\mathrm{Pb}$ & 4.83 & $0-3$ & 3.72 & $12-15$ & 5.85 & $0-3$ & 29.50 & $0-3$ \\
\hline $\mathrm{Hg}$ & 0.41 & $51-54$ & 0.22 & $60-63$ & 0.27 & $0-3$ & 0.33 & $0-3$ \\
\hline
\end{tabular}

Tp: time period of leaching.

\subsubsection{Solution $\mathrm{pH}$}

Considering the natural rainfall conditions, three $\mathrm{pH}$ values, 6.0, 7.0 and 8.0, were examined in Experiments I, II and III in this study. In general, the trends and mean concentrations were similar in the three experiments for each individual element (Tables 4-7), indicating that there was no significant impact of $\mathrm{pH}$ on the leached concentrations and trends of the elements in the coal gangue of the Wulantuga open-cast coal mine area.

Figures 4 and 5 exhibit the changes of leachability of the 12 selected elements from the coal gangue over $90 \mathrm{~h}$. The interrupted curve in the figures indicated that the element concentration in the resulting leachates was less than the black value. The leachability trends of most of the selected elements differed according to the acidity of the leaching solutions. The results of Experiment II, with a $\mathrm{pH}$ of approximately 8.0, differed from those of the other two experiments. For a $\mathrm{pH}$ of 6.0, the leachabilities of the elements from the coal gangue displayed a sharp drop in the initial leaching phase (0-18 h) and then a steady wave-like curve (in descending order of significance), whereas for a $\mathrm{pH}$ of 7.0 , they showed a rise in the initial phase $(0-18 \mathrm{~h})$, followed by a sharp decline and, then, a steady decreasing order wave-like curve. Trace elements $\mathrm{Co}, \mathrm{Ni}, \mathrm{Zn}$ and Se showed almost the same trends of leachabilities in experiments with different $\mathrm{pH}$ values.

In terms of $L_{a m}(\mu \mathrm{g} / \mathrm{g})$ of the elements from the coal gangue in the study area, a slight reverse dependence with the $\mathrm{pH}$ of leaching solutions was observed, which suggested the leachability decreased with increasing $\mathrm{pH}$ (Table 6). Most of the selected elements displayed similar behavior for $L_{r m}$ and $L_{a m}$ under the changing $\mathrm{pH}$ values. However, inconsistency was observed between the trends of $L_{r m}$ and $L_{a m}$ for elements $\mathrm{Co}, \mathrm{Ni}, \mathrm{Cu}$ and $\mathrm{Sn}$. The $L_{r m s}$ values of these four elements remained constant at $0.001 \%, 0.003 \%, 0.002 \%$ and $0.001 \%$, respectively, regardless of the $\mathrm{pH}$ of the leaching solutions (Table 9). As a whole, the $\mathrm{pH}$ values had little impact on the $L_{r m}$ of the 12 elements, but it could influence the $L_{a m}$. 
Table 9. The maximum leached amount $\left(L_{a m}\right)$ and leachability $\left(L_{r m}\right)$ of metals from coal gangue in the Wulantuga open-cast coal mine area.

\begin{tabular}{|c|c|c|c|c|c|c|c|c|}
\hline \multirow{2}{*}{ Elements } & \multicolumn{2}{|c|}{ Experiment I } & \multicolumn{2}{|c|}{ Experiment II } & \multicolumn{2}{|c|}{ Experiment III } & \multicolumn{2}{|c|}{ Experiment IV } \\
\hline & $L_{a m}(\mu \mathrm{g} / \mathrm{g})$ & $L_{r m}(\%)$ & $L_{a m}(\mu \mathrm{g} / \mathrm{g})$ & $L_{r m}(\%)$ & $L_{a m}(\mu \mathrm{g} / \mathrm{g})$ & $L_{r m}(\%)$ & $L_{a m}(\mu \mathrm{g} / \mathrm{g})$ & $L_{r m}(\%)$ \\
\hline As & 0.168 & 0.009 & 0.136 & 0.008 & 0.174 & 0.010 & 0.085 & 0.005 \\
\hline $\mathrm{V}$ & 0.536 & 0.005 & 0.484 & 0.005 & 0.502 & 0.005 & 0.315 & 0.003 \\
\hline $\mathrm{Cr}$ & 0.137 & 0.002 & 0.117 & 0.001 & 0.134 & 0.002 & 0.107 & 0.001 \\
\hline Co & 0.060 & 0.001 & 0.043 & 0.001 & 0.046 & 0.001 & 0.059 & 0.001 \\
\hline $\mathrm{Ni}$ & 0.120 & 0.003 & 0.116 & 0.003 & 0.116 & 0.003 & 0.127 & 0.003 \\
\hline $\mathrm{Cu}$ & 0.072 & 0.002 & 0.071 & 0.002 & 0.069 & 0.002 & 0.089 & 0.002 \\
\hline $\mathrm{Zn}$ & 1.015 & 0.007 & 0.860 & 0.006 & 1.096 & 0.008 & 0.519 & 0.004 \\
\hline Se & 0.079 & 0.105 & 0.060 & 0.079 & 0.061 & 0.081 & 0.096 & 0.127 \\
\hline $\mathrm{Cd}$ & 0.001 & 0.003 & 0.001 & 0.002 & 0.014 & 0.037 & 0.001 & 0.002 \\
\hline Sn & 0.003 & 0.001 & 0.002 & 0.001 & 0.002 & 0.001 & 0.003 & 0.001 \\
\hline $\mathrm{Pb}$ & 0.017 & 0.001 & 0.016 & 0.001 & 0.022 & 0.0014 & 0.038 & 0.001 \\
\hline $\mathrm{Hg}$ & 0.005 & 0.037 & 0.003 & 0.025 & 0.004 & 0.027 & 0.001 & 0.007 \\
\hline
\end{tabular}

\footnotetext{
experiment I
}
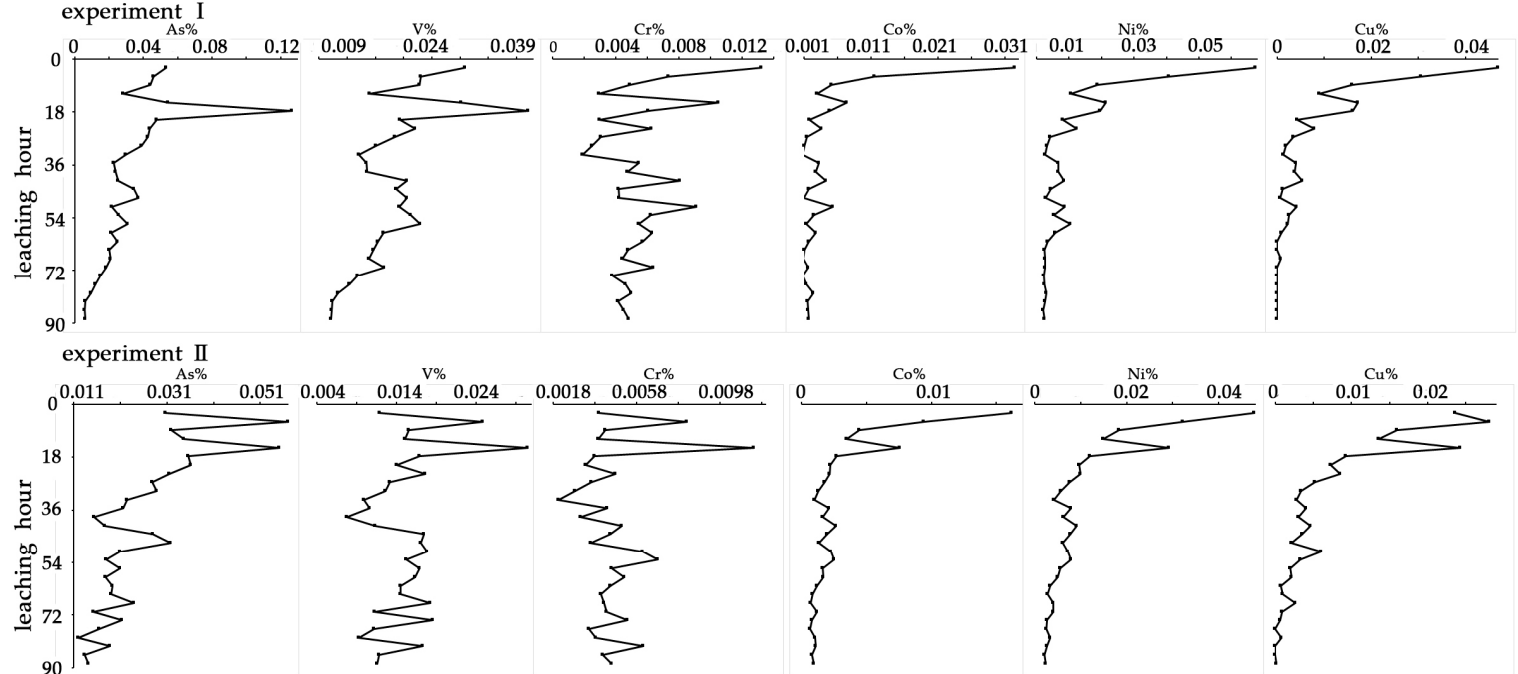

experiment III
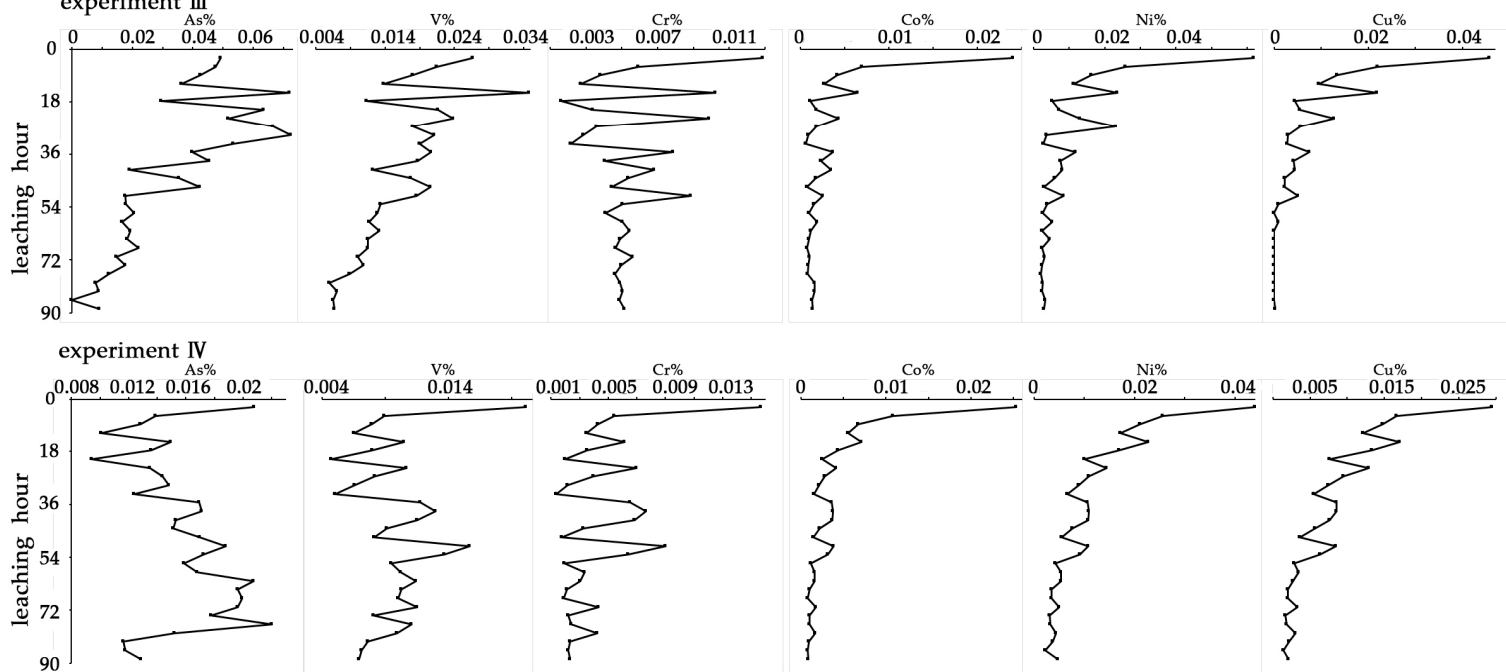

Figure 4. Leachabilities (\%) of the elements $\mathrm{As}, \mathrm{V}, \mathrm{Cr}, \mathrm{Co}, \mathrm{Ni}$ and $\mathrm{Cu}$ from the coal gangue over $90 \mathrm{~h}$ in the four experiments. 


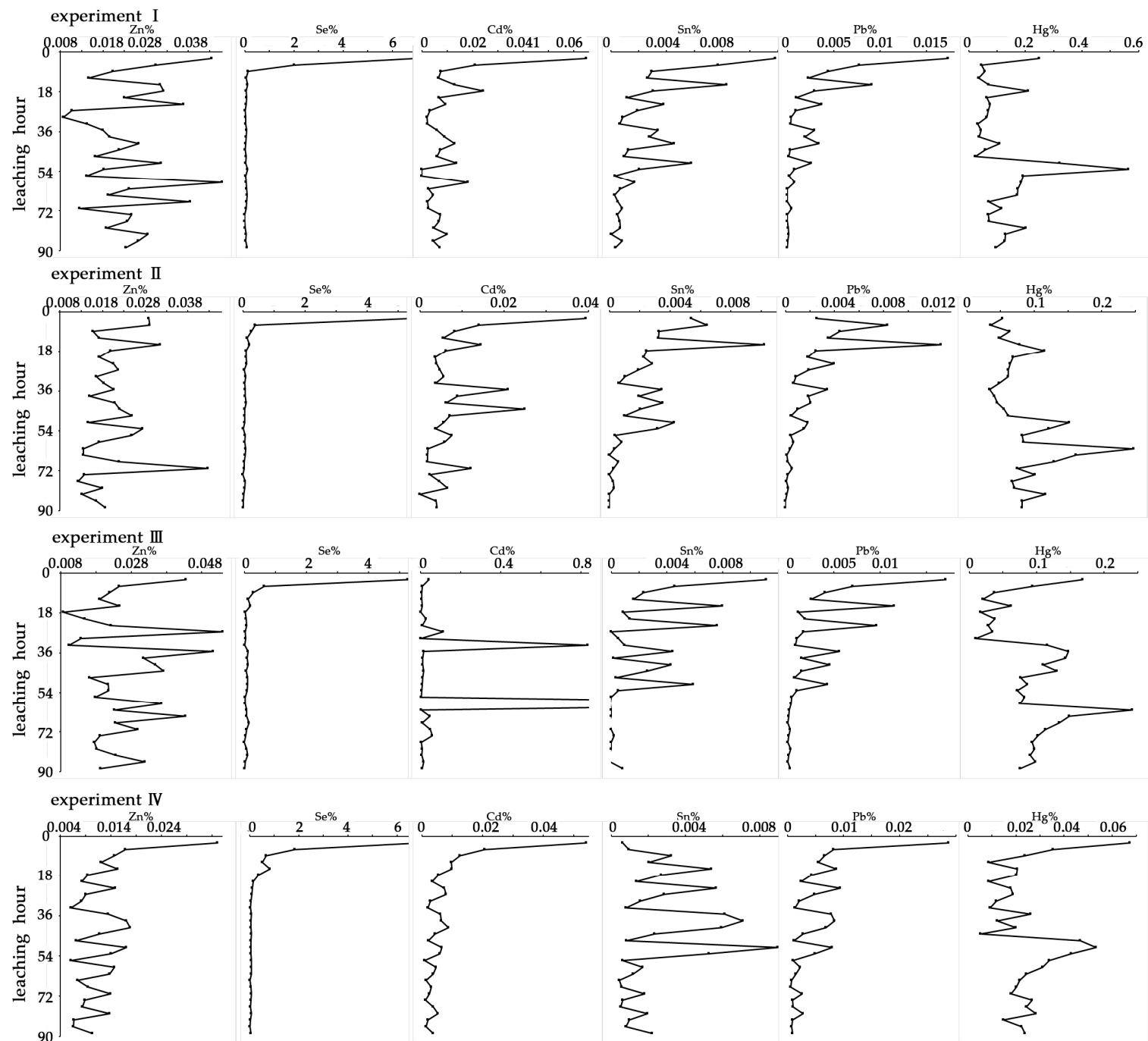

Figure 5. Leachabilities (\%) of the elements $\mathrm{Zn}, \mathrm{Se}, \mathrm{Cd}, \mathrm{Sn}, \mathrm{Pb}$ and $\mathrm{Hg}$ from the coal gangue over $90 \mathrm{~h}$ in the four experiments.

\subsubsection{Sample Amount}

The effects of leaching time and $\mathrm{pH}$ values on the leaching behavior of the elements had previously been investigated $[4,6,34]$. However, the amount of samples was one of the impact factors for the leaching behavior of the elements, especially in column leaching tests. Therefore, the effect of sample amount was further discussed in this study. In the column leaching tests, sample amount should be considered and determined before leaching. Experiment III (30-g of sample) and Experiment IV (45-g of sample), under the same $\mathrm{pH}$ of solutions, were performed to evaluate the role of the mass of coal gangue samples in terms of leaching behavior of the elements, including leached concentrations, leachability, $L_{a m}$ and $L_{r m}$.

All of the selected elements showed much higher leached concentrations with higher sample mass than those with less mass over $90 \mathrm{~h}$, except for As, Cd, Sn and $\mathrm{Hg}$ (Tables 4-7). These four elements were found at almost the same leached concentrations in the two experiments. The leached concentrations reached maximum values in the 0-3-h phase in Experiment IV, with the exception of Sn. For Experiment III, there were four exceptions for the maximum leached concentration, namely As (27-30 h), V (12-25 h), Zn (24-27 h) and Cd (30-33 h).

According to the information displayed above, the sample amount showed little impact on the change trends of the element concentration over time, but a remarkable effect on the analytical 
concentrations of the elements in the resulting leachates. In terms of the changes in leachability of the elements from coal gangue over the leaching time, most of the elements showed little difference between Experiments III and IV (Figures 4 and 5). However, for Cd and Sn, the characteristics of the leachability trends differed significantly between the two experiments (Figure 5). Cd displayed a slow rise followed by a sharp rise and then a sudden wave curve under the condition of less sample mass. However, it showed a sharp initial drop followed by a steadily decreasing wave curve with higher sample mass. Sn exhibited adverse drastic fluctuations, beginning with a sharp decrease (30 g of sample) and increase (45 g of sample) in the two leaching tests (Figure 5). Furthermore, it also exhibited an obvious inverse leachability trend in the latter phase of leaching (45-90 h) for the element of As (Figure 5), which fluctuated with a general decrease in Experiment III and fluctuated with a general increase in Experiment IV. In this study, the $L_{a m}$ and $L_{r m}$ of coal gangue showed no significant effect of sample mass in the leaching tests (Table 6). The $L_{r m}$ of most elements remained invariant, whereas the elements of $\mathrm{V}, \mathrm{Zn}$ and $\mathrm{Hg}$ present a slight decrease with increasing sample mass (Table 9). This indicated that the sample amount perhaps affected the leaching behavior of some environment-sensitive elements.

\subsection{Environmental and Ecological Risk Assessment}

\subsubsection{Environmental Impact}

In comparison with the Clarke values, the concentrations of the trace elements As, Co, Se and $\mathrm{Pb}$ were considerably higher in the coal gangue of the Wulantuga open-cast coal mine area (Table 3). The EF values for As and Se were 4.86 and 7.41, respectively, indicating a high pollution degree due to their high concentration levels $(\mathrm{EF}>2)$.

The $L_{a m}$ values of the selected trace elements provided information of the maximum potential environmental effect of the elements. The results indicated that all of the selected trace elements from coal gangue in the study area had no potential risk to soils and vegetation, based on comparing the $L_{a m}$ values with the corresponding concentrations of the elements defined by the environmental quality standard for soils and limits of contaminants in foods (Tables 9 and 10). In contrast, the elements could perhaps have high potential impacts on the groundwater according to the comparison of $L_{a m}$ with the corresponding concentration in the quality standard for groundwater (Tables 9 and 10). When compared to the quality standard for groundwater, the concentrations of the elements from the water samples were all at an acceptable level. All of the concentrations fell into Grade I (less than the natural background level) for the listing elements in the standard, except for element As, which fell into Grade II (natural background level) (Tables 9 and 10). According to the standard, water in Grade I and Grade II could be used for all kinds of purposes, including those of drinking water. For the concentrations of soil samples, elements $\mathrm{Ni}, \mathrm{Pb}$ and $\mathrm{Hg}$ were found in Level 1 (natural background level), and $\mathrm{As}, \mathrm{Cr}, \mathrm{Cu}, \mathrm{Zn}$ and $\mathrm{Cd}$ fell into Level 2 (no pollution to vegetation and the environment) (Tables 3 and 10). However, in terms of the vegetation samples, almost all of the element concentrations were higher than those defined in the limits of contaminants in foods (Tables 3 and 10).

\subsubsection{Ecological Risk}

ERL and ERM values were employed to evaluate the biological toxicity of the selected trace elements. According to Table 3, it could be found that $\mathrm{Ni}$ was in the probable biological effects category (>ERMs value) for $50 \%$ of the coal gangue samples from the Wulantuga open-cast coal mine area. For As, $\mathrm{Cr}$ and $\mathrm{Zn}, 50 \%$ of samples were in the middle range, i.e., occasional adverse biological effects $(>$ ERL and $<$ ERM) predicted. Therefore, the 12 sensitive environmental trace elements from coal gangue in the study produced moderate to high ecological hazard to the environment. 
Table 10. Concentrations of trace elements defined in groundwater, soils and foods.

\begin{tabular}{|c|c|c|c|c|c|c|c|c|c|c|c|}
\hline \multirow{3}{*}{ Element } & \multicolumn{5}{|c|}{ Quality Standard for Ground Water ${ }^{1}(\mu \mathrm{g} / \mathrm{L})$} & \multicolumn{5}{|c|}{ Environmental Quality Standard for Soils ${ }^{2}(\mu \mathrm{g} / \mathrm{L})$} & \multirow{3}{*}{ Limits of Contaminants in Foods ${ }^{3}(\mu \mathrm{g} / \mathrm{g})$} \\
\hline & \multirow{2}{*}{ Grade I } & \multirow{2}{*}{ Grade II } & \multirow{2}{*}{ Grade III } & \multirow{2}{*}{ Grade IV } & \multirow{2}{*}{ Grade V } & \multicolumn{2}{|l|}{ Level One } & \multicolumn{2}{|l|}{ Level Two } & \multirow{2}{*}{$\begin{array}{c}\text { Level Three } \\
\mathrm{pH}>6.5\end{array}$} & \\
\hline & & & & & & Natural Background & $\mathrm{pH}<6.5$ & pH 6.5-7.5 & $\mathrm{pH}<7.5$ & & \\
\hline As & $\leqslant 5$ & $\leqslant 10$ & $\leqslant 50$ & $\leqslant 50$ & $>50$ & $\leqslant 15$ & $\leqslant 40$ & $\leqslant 30$ & $\leqslant 25$ & $\leqslant 40$ & $\leqslant 0.5$ \\
\hline $\mathrm{V}$ & - & - & - & - & - & - & - & - & - & - & - \\
\hline $\mathrm{Cr}$ & $\leqslant 5$ & $\leqslant 10$ & $\leqslant 50$ & $\leqslant 100$ & $>100$ & $\leqslant 90$ & $\leqslant 150$ & $\leqslant 200$ & $\leqslant 250$ & $\leqslant 300$ & $\leqslant 0.5$ \\
\hline Co & $\leqslant 5$ & $\leqslant 50$ & $\leqslant 50$ & $\leqslant 1000$ & $>1000$ & - & - & - & - & - & - \\
\hline $\mathrm{Ni}$ & $\leqslant 5$ & $\leqslant 50$ & $\leqslant 50$ & $\leqslant 100$ & $>100$ & $\leqslant 40$ & $\leqslant 40$ & $\leqslant 50$ & $\leqslant 60$ & $\leqslant 200$ & $\leqslant 1.0$ \\
\hline $\mathrm{Cu}$ & $\leqslant 10$ & $\leqslant 50$ & $\leqslant 1000$ & $\leqslant 1500$ & $>1500$ & $\leqslant 35$ & $\leqslant 50$ & $\leqslant 100$ & $\leqslant 100$ & $\leqslant 400$ & - \\
\hline $\mathrm{Zn}$ & $\leqslant 50$ & $\leqslant 500$ & $\leqslant 1000$ & $\leqslant 5000$ & $>5000$ & $\leqslant 100$ & $\leqslant 200$ & $\leqslant 250$ & $\leqslant 300$ & $\leqslant 500$ & - \\
\hline Se & $\leqslant 10$ & $\leqslant 10$ & $\leqslant 10$ & $\leqslant 100$ & $>100$ & - & - & - & - & - & - \\
\hline $\mathrm{Cd}$ & $\leqslant 0.1$ & $\leqslant 1$ & $\leqslant 10$ & $\leqslant 10$ & $>10$ & $\leqslant 0.20$ & $\leqslant 0.30$ & $\leqslant 0.60$ & $\leqslant 1.0$ & - & $\leqslant 0.2$ \\
\hline Sn & & & & & & & & end & & - & $\leqslant 250$ \\
\hline $\mathrm{Pb}$ & $\leqslant 5$ & $\leqslant 10$ & $\leqslant 50$ & $\leqslant 100$ & $>100$ & $\leqslant 35$ & $\leqslant 250$ & $\leqslant 300$ & $\leqslant 350$ & $\leqslant 500$ & $\leqslant 0.3$ \\
\hline $\mathrm{Hg}$ & $\leqslant 0.05$ & $\leqslant 0.5$ & $\leqslant 1$ & $\leqslant 1$ & $>1$ & $\leqslant 0.15$ & $\leqslant 0.30$ & $\leqslant 0.50$ & $\leqslant 1.0$ & $\leqslant 1.5$ & $\leqslant 0.01$ \\
\hline
\end{tabular}

${ }^{1} \mathrm{~GB} / \mathrm{T} 14848-93$ [41]; ${ }^{2}$ GB15618-1995 [42]; ${ }^{3}$ GB2762-2012 [43]. "-_" means data are not available. 


\section{Discussion}

\subsection{Leaching Behavior and Experimental Procedures}

The leaching behavior of the elements from the coal gangue is affected by various factors. Leaching time, $\mathrm{pH}$ values and sample amount were discussed to evaluate their roles in terms of the leaching behavior of the elements of the resulting leachates from the coal gangue in the Wulantuga open-cast coal mine area. The results of this study show that leaching time and sample mass have relatively obvious effects on the concentrations, leached amounts and leachability of elements. This result is consistent with the conclusions of other research $[4,17,19,44,45]$.

Many previous studies suggested that the leaching behavior of the elements was closely associated with $\mathrm{pH}$ values in the leaching solutions $[4,19,20,45]$. However, it shows little role in the current study. Considering the natural conditions of rainfall, $\mathrm{pH}$ varies from 6.60-8.19 in the study area, and the $\mathrm{pH}$ values applied to evaluate its effect are 6.0, 7.0 and 8.0. These three values are consistent with the natural conditions, but could not demonstrate the effect of solution acidity or alkalinity. In this study, leaching behavior is considered to include the leached concentrations of the elements, leached amount, leachability, $L_{a m}$ and $L_{r m}$. Fraction profiles of the elements could further assess the potential risks posed by the elements from coal gangue [6,46]. In future research, the fraction profiles, water-leachable, ion-changeable, carbonate-bound, organic-bound, silicate-bound and sulfide-bound particles of the selected 12 elements will be investigated.

\subsection{Quantitative Analysis of Environmental Impacts}

The assessment of the impact of trace elements from coal gangue on vegetation indicates that little potential risk exists to the plants around the open-cast coal mine area based on comparing $L_{a m}$ values of the elements to corresponding concentrations in the limits of contaminants in foods, which could indirectly provide information of the impacts on human health. However, the trace element concentrations of the vegetation samples are higher than those of the limits for all of the selected elements (As, Cr, Ni, Cd, Pb and $\mathrm{Hg}$ ) listed in the limits of contaminants in foods, except for Sn. This suggests that coal gangue contributed little to the concentrations of trace elements in vegetation in the study area, which are obviously not suitable for food consumption.

In addition to the method of contrasting standards, EF values, $L_{a m}, L_{r m}$, ERL and ERM values were also applied to assess the trace element potential environmental and ecological hazards. These methods could be defined as semi-quantitative analyses for the trace element potential environmental and ecological impacts. Furthermore, the spatial extent and levels of pollution exposed by the trace element dispersal from coal gangue in coal mines are critical in determining the best measures and techniques for preventing environmental pollution and reclamation. The trace element transport pathways and the extent of potential environmental pollution should be identified by in situ sampling and analysis with the help of GIS in future research. Based on a large number of studies, a quantitative model of the trace element leaching behavior could be developed to evaluate environmental and ecological potential risks.

\section{Conclusions}

The changes of concentrations, leached amount, leachability, $L_{a m}$ and $L_{r m}$ of the selected 12 trace elements from coal gangue in the Wulantuga open-cast coal mine area, Inner Mongolia, China, were investigated in this study. Based on the results of leaching behavior, the potential environmental and ecological hazards were also evaluated through different methods.

Leaching time and sample mass play important roles in determining the trace element concentrations, the leached amounts and leachabilities. $\mathrm{pH}$ values do not exhibit an obvious effect on the leaching behavior in this study. The coal gangue is enriched in $\mathrm{As}, \mathrm{Co}$, Se and $\mathrm{Pb}$, and the EF values of As and Se indicate higher environmental pollution levels. All of the selected trace elements, namely, As, V, Cr, Co, Ni, Cu, Zn, Se, Cd, Sn, Pb and $\mathrm{Hg}$, show no potential risk to soils and vegetation, 
but high potential risk to groundwater, based on the analysis of $L_{a m}$ values. Simultaneously, according to the ERL and ERM values in the SQGs, Ni from the coal gangue is inclined to have high biological toxicity, and As, Cr and Zn show moderate ecological risk to the environment. Further research of the environment-sensitive trace element leaching behavior should be investigated through more quantitative methods with the aid of GIS to identify environmental pollution and effectively make decisions regarding prevention and reclamation.

Acknowledgments: This work is supported by the National Basic Research Program of China (973 Program, No. 2014CB238906). We thank Shifeng Dai at China University of Mining \& Technology (Beijing) for his suggestions about the leaching tests and assisting in the ICP-MS analysis of the trace elements in coal gangue, the resulting leachates, soil, water and vegetation samples. We thank Xibo Wang at China University of Mining \& Technology (Beijing) for his help with the XRF and XRD analysis of the chemical and mineral compositions of coal gangue. Two anonymous reviewers are especially thanked for their valuable comments, which greatly improved the paper quality.

Author Contributions: Liu Yang performed the analysis and designed the evaluation methods. Liu Yang, Jianfei Song and Bo Song helped to conceive of and design the experiments. Jianfei Song, Ruduo Wang and Bo Song performed the experiments. Liu Yang, Xue Bai and Jianfei Song analyzed the data. Xue Bai contributed to the standards and analysis. Jianfei Song and Tianhao Zhou developed the figures and tables. Jianli Jia and Haixia Pu provided the water and vegetation samples. Liu Yang and Xue Bai wrote the paper.

Conflicts of Interest: The authors declare no conflicts of interest.

\section{References}

1. Dai, S.; Ren, D.; Chou, C.; Finkelman, R.; Vladimir, V.; Zhou, Y. Geochemistry of trace elements in Chinese coals: A review of abundances, genetic types, impacts on human health, and industrial utilization. Int. J. Coal Geol. 2012, 94, 3-21. [CrossRef]

2. Hower, J.C.; Robl, T.L.; Anderson, C.; Thomas, G.A.; Sakulpitakphon, T.; Mardon, S.M.; Clark, W.L. Characteristics of coal combustion products (CCP's) from Kentucky power plants, with emphasis on mercury content. Fuel 2005, 84, 1338-1350. [CrossRef]

3. Park, K.S.; Seo, Y.C.; Lee, S.J.; Lee, J.H. Emission and speciation of mercury from various combustion sources. Powder Technol. 2008, 180, 151-156. [CrossRef]

4. Wang, W.; Qin, Y.; Song, D.; Song, D.; Wang, K. Column leaching of coal and its combustion residues, Shizuishan, China. Int. J. Coal Geol. 2008, 75, 81-87. [CrossRef]

5. Finkelman, R.B.; Orem, W.; Castranova, V.; Tatu, C.A.; Belkin, H.E.; Zheng, B.; Lerch, H.E.; Maharaj, S.V.; Bates, A.L. Health impacts of coal and coal use: Possible solutions. Int. J. Coal Geol. 2002, 50, 425-443. [CrossRef]

6. Zhou, C.; Liu, G.; Wu, D.; Fang, T.; Wang, R.; Fan, X. Mobility behavior and environmental implications of trace elements associated with coal gangue: A case study at the Huainan Coalfield in China. Chemosphere 2014, 95, 193-199.

7. Bhattacharya, A.; Routh, J.; Jacks, G.; Bhattacharya, P.; Morth, M. Environmental assessment of abandoned mine tailings in Adak, Västerbotten district (northern Sweden). Appl. Geochem. 2006, 21, 1760-1780. [CrossRef]

8. $\mathrm{Si}, \mathrm{H} . ; \mathrm{Bi}, \mathrm{H} . ; \mathrm{Li}, \mathrm{X} . ;$ Yang, C. Environmental evaluation for sustainable development of coal mining in Qijiang, Western China. Int. J. Coal Geol. 2010, 81, 163-168. [CrossRef]

9. Querol, X.; Izquierdo, M.; Monfort, E.; Alvarez, E.; Font, O.; Moreno, T.; Alastuey, A.; Zhuang, X.; Lu, W.; Wang, Y. Environmental characterization of burnt coal gangue banks at Yangquan, Shanxi Province, China. Int. J. Coal Geol. 2008, 75, 93-104. [CrossRef]

10. Yue, M.; Zhao, F. Leaching experiments to study the release of trace elements from mineral separates from Chinese coals. Int. J. Coal Geol. 2008, 73, 43-51. [CrossRef]

11. Kang, Y.; Liu, G.; Chou, C.L.; Wong, M.; Zheng, L.; Ding, R. Arsenic in Chinese coals: Distribution, modes of occurrence, and environmental effects. Sci. Total Environ. 2011, 412-413, 1-13. [CrossRef] [PubMed]

12. Swaine, D.J. Why trace elements are important. Fuel Process. Technol. 2000, 65-66, 21-23. [CrossRef]

13. Dai, S.; Ren, D.; Tang, Y.; Yue, M.; Hao, L. Concentration and distribution of elements in Late Permian coals from western Guizhou Province, China. Int. J. Coal Geol. 2005, 61, 119-137. [CrossRef] 
14. Chen, J.; Liu, G.; Kang, Y.; Wu, B.; Sun, R.; Zhou, C.; Wu, D. Atmospheric emissions of F, As, Se, Hg, and Sb from coal-fired power and heat generation in China. Chemosphere 2013, 90, 1925-1932. [CrossRef] [PubMed]

15. Praharaj, T.; Powell, M.A.; Hart, B.R.; Tripathy, S. Leachability of elements from sub-bituminous coal fly ash from India. Environ. Int. 2002, 27, 609-615. [CrossRef]

16. Hassett, D.; Pflughoeft-Hassett, D.; Heebink, L. Leaching of CCBs: Observations from over 25 years of research. Fuel 2005, 84, 1378-1383. [CrossRef]

17. Izquierdo, M.; Querol, X. Leaching behaviour of elements from coal combustion fly ash: An overview. Int. J. Coal Geol. 2012, 94, 54-66. [CrossRef]

18. Zhou, C.; Liu, G.; Yan, Z.; Fang, T.; Wang, R. Transformation behavior of mineral composition and trace elements during coal gangue combustion. Fuel 2012, 97, 644-650. [CrossRef]

19. Peng, B.; Wu, D. Leaching characteristics of bromine in coal. J. Fuel Chem. Technol. 2011, 39, 647-651. [CrossRef]

20. Huggins, F.E.; Seidu, L.B.A.; Shah, N.; Backus, J.; Huffman, G.P.; Honaker, R.Q. Mobility of elements in long-term leaching tests on Illinois \#6 coal rejects. Int. J. Coal Geol. 2011, 94, 326-336.

21. Du, G.; Zhuang, X.; Querol, X.; Izquierdo, M.; Alastuey, A.; Moreno, T.; Font, O. Ge distribution in the Wulantuga high-germanium coal deposit in the Shengli coalfield, Inner Mongolia, northeastern China. Int. J. Coal Geol. 2009, 78, 16-26. [CrossRef]

22. Dai, S.; Liu, J.; Ward, C.R.; Hower, J.C.; Xie, P.; Jiang, Y.; Hood, M.M.; O’Keefe, J.M.K.; Song, H. Petrological, geochemical, and mineralogical compositions of the low-Ge coals from the Shengli Coalfield, China: A comparative study with Ge-rich coals and a formation model for coal-hosted Ge ore deposit. Ore Geolo. Rev. 2015, 71, 318-349. [CrossRef]

23. Jia, J.; Li, X.; Wu, P.; Liu, Y.; Han, C.; Zhou, L.; Yang, L. Human health risk assessment and safety threshold of harmful trace elements in the soil environment of the Wulantuga open-cast coal mine. Minerals 2015, 5, 837-848. [CrossRef]

24. Dai, S.; Wang, X.; Seredin, V.; Hower, J.C.; Ward, C.R.; O’Keefe, J.M.; Huang, W.; Li, T.; Li, X.; Liu, H.; et al. Petrology, mineralogy, and geochemistry of the Ge-rich coal from the Wulantuga Ge ore deposit, Inner Mongolia, China: New data and genetic implications. Int. J. Coal Geol. 2012, 90-91, 72-99. [CrossRef]

25. Zhuang, X.; Querol, X.; Alastuey, A.; Juan, R.; Plana, F.; Lopez-Soler, A.; Du, G.; Martynov, V.V. Geochemistry and mineralogy of the Cretaceous Wulantuga high germanium coal deposit in Shengli coal field, Inner Mongolia, Northeastern China. Int. J. Coal Geol. 2006, 66, 119-136. [CrossRef]

26. Dai, S.; Seredin, V.V.; Ward, C.R.; Jiang, J.; Hower, J.C.; Song, X.; Jiang, Y.; Wang, X.; Gornostaeva, T.; Li, X.; et al. Composition and modes of occurrence of minerals and elements in coal combustion products derived from high-Ge coals. Int. J. Coal Geol. 2014, 121, 79-97. [CrossRef]

27. Dai, S.; Hower, J.C.; Ward, C.R.; Guo, W.; Song, H.; O'Keefe, J.M.K.; Xie, P.; Hood, M.M.; Yan, X. Elements and phosphorus minerals in the middle Jurassic inertinite-rich coals of the Muli Coalfield on the Tibetan Plateau. Int. J. Coal Geol. 2015, 144-145, 23-47. [CrossRef]

28. Dai, S.; Wang, P.; Ward, C.R.; Tang, Y.; Song, X.; Jiang, J.; Hower, J.C.; Li, T.; Seredin, V.V.; Wagner, N.J.; et al. Elemental and mineralogical anomalies in the coal-hosted Ge ore deposit of Lincang, Yunnan, southwestern China: Key role of $\mathrm{N}_{2}-\mathrm{CO}_{2}$-mixed hydrothermal solutions. Int. J. Coal Geol. 2015, 152, 19-46. [CrossRef]

29. Li, X.; Dai, S.; Zhang, W.; Li, T.; Zheng, X.; Chen, W. Determination of As and Se in coal and coal combustion products using closed vessel microwave digestion and collision/reaction cell technology (CCT) of inductively coupled plasma mass spectrometry (ICP-MS). Int. J. Coal Geol. 2014, 124, 1-4. [CrossRef]

30. Dai, S.; Li, T.; Jiang, Y.; Ward, C.R.; Hower, J.C.; Sun, J.; Liu, J.; Song, H.; Wei, P.; Li, Q.; et al. Mineralogical and geochemical compositions of the Pennsylvanian coal in the Hailiushu Mine, Daqingshan Coalfield, Inner Mongolia, China: Implications of sediment-source region and acid hydrothermal solutions. Int. J. Coal Geol. 2015, 137, 92-110. [CrossRef]

31. Liu, K.; Wang, X.; Sun, H.; Chen, L. PH value and acid rain condition in Inner Mongolia area in recent 3 years. Meteorol. J. Inn. Mongolia 2010, 3, 32-33.

32. Duce, R.A.; Hoffmann, G.L.; Zoller, W.H. Atmospheric trace metals at remote northern and southern hemisphere sites: Pollution or natural? Science 1975, 187, 59-61. [CrossRef] [PubMed]

33. Bai, X.; Jia, H. The release of heavy metals in Gangue Leaching Process. Environ. Sci. Tech. 2009, 22, 5-8. 
34. Wang, W.; Hao, W.; Bian, Z.; Lei, S.; Wang, X.; Sang, S. Effect of coal mining activities on the environment of Tetraenamongolica in Wuhai, Inner Mongolia, China-A geochemical perspective. Int. J. Coal Geol. 2014, 132, 94-102. [CrossRef]

35. Pekey, H.; Karakas, D.; Ayberk, S.; Tolun, L.; Bakoglu, M. Ecological risk assessment using trace elements from surface sediments of Izmit Bay (Northeastern Marmara Sea) Turkey. Mar. Pollut. Bull. 2004, 48, 946-953. [CrossRef] [PubMed]

36. Thomas, L. Coal Geology, 2nd ed.; John Wiley \& Sons Inc.: Hoboken, NJ, USA, 2012; p. 454.

37. ASTM International. Test Method for Moisture in the Analysis Sample of Coal and Coke; ASTM Standard D3173-11; ASTM International: West Conshohocken, PA, USA, 2011.

38. ASTM International. Annual Book of ASTM Standards. In Test Method for Ash in the Analysis Sample of Coal and Coke; ASTM Standard D3174-11; ASTM International: West Conshohocken, PA, USA, 2011.

39. Dai, S.; Graham, I.T.; Ward, C.R. A review of anomalous rare earth elements and yttrium in coal. Int. J. Coal Geol. 2016, 159, 82-95. [CrossRef]

40. Tayor, S.R. Abundance of chemical elements in the continental crust: a new table. Int. J. Geochim. Cosmochim. Acta. 1964, 28, 1273-1285.

41. General Administration of Quality Supervision. Quality Standard for Ground Water; GB/T 14848-1993; General Administration of Quality Supervision: Beijing, China, 1993. (In Chinese)

42. General Administration of Quality Supervision. Environmental Quality Standard for Soils; GB 15618-1995; General Administration of Quality Supervision: Beijing, China, 1995. (In Chinese)

43. Ministry of Health P.R. China. National Food Safety Standard of Maximum Levels of Contaminants in Foods; GB 2762-2012. Ministry of Health P.R. China: Beijing, China, 2012. (In Chinese).

44. Guo, Y.; Huang, P.; Zhang, W. Leaching of heavy metals from Dexing copper mine tailings pond. Trans. Nonferrous Met. Soc. China 2013, 23, 3068-3075. [CrossRef]

45. Spears, D.A. The determination of trace element distributions in coals using sequential chemical leaching-A new approach to an old method. Fuel 2013, 114, 31-37. [CrossRef]

46. DeLemos, L.J.; Brugge, D.; Cajero, M.; Durant, J.L.; George, C.M.; Henio-Adeky, S.; Nez, T.; Manning, T.; Rock, T.; Seschillie, B.; et al. Development of risk maps to minimize uranium exposures in the Navajo Church rock mining district. Environ. Health 2009, 8, 29. [CrossRef] [PubMed]

(C) 2016 by the authors; licensee MDPI, Basel, Switzerland. This article is an open access article distributed under the terms and conditions of the Creative Commons Attribution (CC-BY) license (http://creativecommons.org/licenses/by/4.0/). 